\title{
PEDAGOGI KRITIS: PEMIKIRAN HENRY GIROUX TENTANG PENDIDIKAN DAN RELEVANSINYA UNTUK INDONESIA
}

\section{Reza Antonius Alexander Wattimena}

Alumnus Post Doktoral di Hochschule für Philosophie München,

Philosophische Fakultät SJ München, Jerman

Email : reza.antonius@gmail.com

\section{Abstrak}

Tulisan ini merupakan kritik terhadap pedagogi tradisional di dalam pendidikan dengan menggunakan konsep pedagogi kritis yang dirumuskan oleh Henry Giroux. Pedagogi kritis berupaya mempertanyakan dan mengungkap hubungan-hubungan kekuasaan di dalam masyarakat yang menciptakan penindasan dan ketidakadilan sosial. Ia menyediakan wawasan yang luas sekaligus kepekaan moral untuk mendorong orang terlibat di dalam perubahan sosial, guna menciptakan masyarakat yang lebih bebas dan adil. Pedagogi kritis hendak mempertanyakan pola pikir neoliberalisme yang kini merasuki berbagai bidang kehidupan manusia. Tulisan ini juga melihat kemungkinan menerapkan konsep pedagogi kritis dari Henry Giroux untuk konteks Indonesia.

Kata kunci: Pedagogi Tradisional, Pedagogi Kritis, Neoliberalisme

\section{Abstract}

This paper is a critique toward traditional pedagogy in education through a critical pedagogy perspective as formulated by Henry Giroux. Critical pedagogy is an attempt to question and to uncover the existing power relations in society which create various forms of subordination and social injustice. Critical pedagogy offers extended perspective as well as moral sensibility that encourage engagement in efforts of bringing social changes to produce freedom and justice in the society. According to Giroux, critical pedagogy provides various theoretical tools to examine neoliberalist mindset that spreads in various dimensions of human life. This writing furtjer seeks possibility to apply the concept of critical pedagogy in Indonesian context.

Keywords: Traditional Pedagogy, Critical Pedagogy, Neoliberalism 


\section{PENDAHULUAN}

Selama ini, pedagogi dipahami sebagai metode pengajaran. Di dalamnya terkandung berbagai teori tentang pendidikan, pengajaran serta beragam pandangan tentang manusia dan hubungan antar manusia. Dengan teorinya tentang pedagogi kritis, Henry Giroux hendak memperluas makna pedagogi menjadi paradigma kehidupan, yakni pandangan yang dianut seseorang secara mendalam di dalam melihat hubungannya dengan dunia dan orang lain. Paradigma ini bersikap kritis. Artinya, ia mempertanyakan hubungan-hubungan kekuasaan yang terletak di dalam masyarakat, sehingga menghasilkan pola masyarakat tertentu.

Sikap kritis ini dibarengi oleh dua hal, yakni keluasan wawasan dan kepekaan moral. Wawasan yang luas, dalam arti ini, adalah kemampuan untuk melihat sebuah persoalan dalam kaitan dengan persoalan-persoalan lainnya. Dasarnya adalah kesadaran akan kesalingterhubungan dari segala sesuatu. Ini tentunya dibarengi dengan kepekaan moral, yakni kemampuan untuk membuat penilaian baik dan buruk terhadap suatu peristiwa dengan dasardasar yang masuk akal. Dengan perpaduan antara sikap kritis, keluasan wawasan serta kepekaan moral, pedagogi kritis lalu bisa menjadi inspirasi bagi pendidikan untuk mendorong keterlibatan sosial, dan membawa perubahan di dalam masyarakat.

Tulisan ini hendak melihat unsur-unsur penting di dalam pedagogi kritis yang dirumuskan Giroux, serta melihat kemungkinan penerapannya di Indonesia. Tulisan ini dibagi ke dalam lima bagian. Bagian pertama menjelaskan sedikit soal latar belakang hidup maupun pemikiran Henry Giroux. Bagian kedua menjelaskan inti pandangan Giroux tentang pedagogi kritis. Bagian ketiga menunjukan beberapa kemungkinan penerapan pemikiran Giroux dalam konteks Indonesia. Bagian keempat merupakan tanggapan kritis terhadap pemikiran Giroux. Bagian kelima merupakan kesimpulan dari tulisan ini.

\section{HENRY GIROUX DAN PEDAGOGI KRITIS}

Henry Giroux lahir pada 18 September 1943. Ia adalah pemikir Amerika Serikat yang kemudian pindah ke Kanada. Ia juga dikenal 
sebagai salah satu pendiri pedagogi kritis (Critical Pedagogy). Di dalam pedagogi kritis, ia mengaitkan ilmu pendidikan, kajian budaya, kajian politik, kajian media dan teori kritis. Giroux juga ditempatkan sebagai salah satu dari lima puluh pemikir pendidikan yang paling berpengaruh di dunia modern. Ia mengajar di berbagai institusi pendidikan, mulai dari Universitas Boston, Miami dan Penn State. Pada 2005 lalu, Giroux menjadi Profesor di McMaster University, Kanada. Sepanjang karirnya, ia telah menulis lebih dari 60 buku, dan berbagai artikel yang telah diterbitkan di berbagai media.

Giroux mendapatkan gelar doktor dari Universitas CarnegieMellon pada 1977. Kemudian, ia menjadi profesor dalam bidang pendidikan di Universitas Boston sampai 1983. Pada tahun itu, ia pindah ke Universitas Miami. Disana, namanya mulai dikenal sebagai seorang pemikir besar di bidang pendidikan. Di Miami, ia juga menjadi kepala dari pusat penelitian pendidikan dan kajian budaya. Dari 1992 sampai 2004, ia mengajar sebagai profesor pendidikan di Penn State University. Ia juga menjadi kepala dari forum pendidikan dan kajian budaya disana. Pada 2004 lalu, ia pindah ke McMaster University di Kanada sebagai profesor dalam bidang pendidikan dan kepentingan publik (Education and Public Interest). Pada 2012 sampai 2015, ia juga menjadi visiting professor di Ryerson University (Giroux, 2018).

Penerbit buku ilmiah, Routledge, bahkan memasukan Giroux ke dalam daftar pemikir pendidikan yang paling berpengaruh dunia. Pandangan Giroux tentang pendidikan telah mengubah wajah dunia pendidikan modern. Ini rupanya juga dipertegas dengan penghargaan yang diberikan oleh Pemerintah Kanada pada 2007 lalu. Giroux menerima Toronto Star yang merupakan lambang bagi orangorang Kanada yang ikut membentuk pemikiran dunia modern. Kemudian, ia menerima tiga gelar Doctor Honoris Causa dari Chapman University, Memorial University and University of West Scotland. Di samping itu, Giroux juga dipercaya menjadi editor sekaligus penasihat dari berbagai jurnal ilmiah internasional.

Selama beberapa waktu, Giroux bekerja sama dengan Paulo Freire untuk menerbitkan beberapa buku tentang pendidikan dan kajian budaya. Di sisi lain, Giroux juga banyak menyumbangkan 
tulisan-tulisannya untuk berbagai portal berita online dan berbagai jurnal ilmiah lainnya. Ia juga menulis di berbagai koran nasional AS, seperti New York Times dan Washington Post. Berbagai bukunya juga diterjemahkan ke beberapa bahasa. Penelitian Giroux tersebar mulai dari kajian budaya, pendidikan, pedagogi kritis, kajian media, teori sosial dan politik pendidikan. Ia melakukan banyak kritik tajam terhadap cara pandang neoliberalisme yang tidak hanya menghantam dunia ekonomi dunia, tetapi juga pendidikan dan budaya pada umumnya.

Banyak ahli pendidikan yang mengharapkan, supaya Indonesia melakukan reformasi pendidikan. Namun, konsep ini, yakni reformasi pendidikan, tetap tidak jelas. Menurut Giroux, secara global, konsep reformasi pendidikan biasanya justru diajukan untuk mengubah pendidikan menjadi semakin tidak kritis (Giroux, 2011). Yang kemudian terjadi, pendidikan menjadi semakin otoriter, sehingga membunuh kebebasan dan kesempatan bertanya, serta menciptakan ketidakpedulian terhadap segala permasalahan yang terjadi. Pedagogi kritis, sebagaimana dirumuskan oleh Giroux, hendak melawan kecenderungan semacam itu. Di dalam pandangan ini, pendidikan dilihat sebagai sesuatu yang amat penting di dalam pengembangan demokrasi. Demokrasi tidak akan dapat terbentuk, tanpa adanya budaya pendidikan yang mampu mendorong semua warga untuk berpikir kritis, reflektif, berwawasan luas, mampu membuat penilaian moral yang seimbang, serta bertindak dengan memperhatikan tanggung jawab sosial, seperti tergambar dalam Bagan 1 (Wattimena, 2018).

"Saya mengenal sejak awal," demikian tulis Giroux, "bahwa pedagogi kritis sebagai praktek moral dan politis melakukan lebih dari sekedar penekanan terhadap analisis kritis dan penilaian moral"(Giroux, 2011: 3). Pedagogi kritis, tambahnya, menawarkan pisau untuk melakukan kritik terhadap pandangan-pandangan lama yang sudah ketinggalan jaman, merumuskan pandangan baru tentang manusia dalam hubungannya dengan lingkungan sosial, dan mendorong orang untuk terlibat di dalam proses pembentukan masyarakat demokratis yang adil dan makmur. 


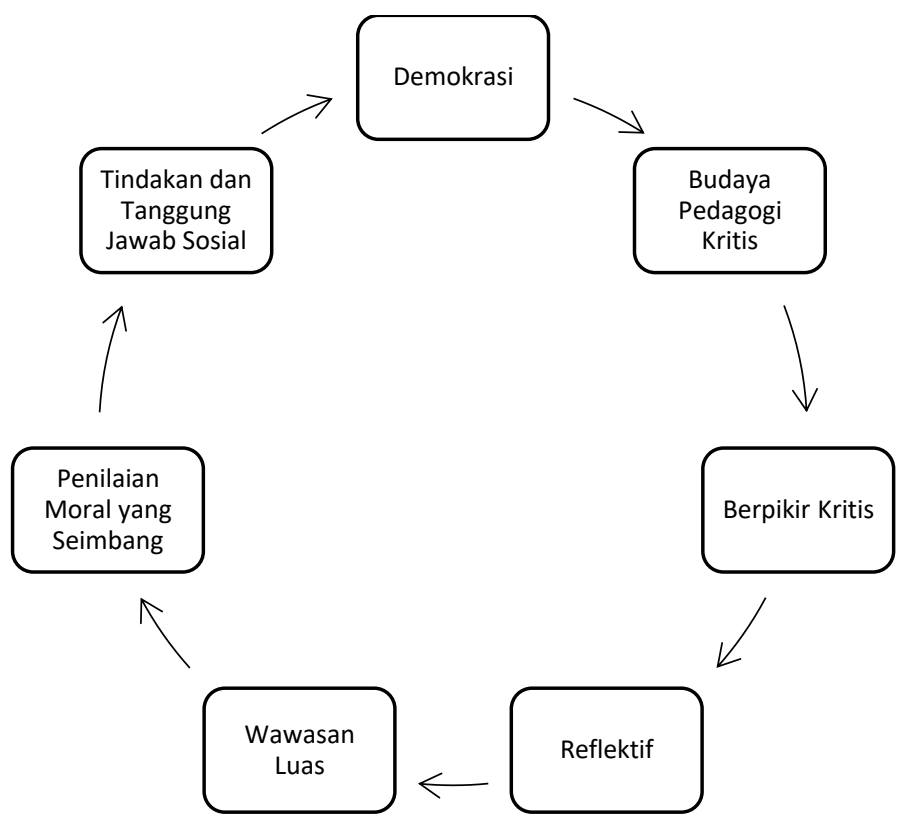

Bagan 1. Proses Pembentukan Demokrasi

Pedagogi kritis menjadi semakin penting, ketika orang hidup dalam masyarakat yang penuh dengan penindasan dan ketidakadilan. Di dalam masyarakat semacam itu, banyak orang tak memiliki kesempatan untuk menentukan hidupnya sendiri, dan ikut mengatur masyarakatnya. Pendek kata, ia tidak dapat mengekspresikan kemanusiaannya secara penuh. Dalam masyarakat semacam ini, menurut Giroux, pedagogi kritis bisa menjadi alat untuk membangun kesadaran dan mendorong perubahan sosial secara luas. Ia adalah sebentuk tindakan teoritis sekaligus politis untuk memahami serta mengubah masyarakat. Pedagogi kritis lebih dari sekedar metode kering yang biasanya digunakan di dalam penelitian dan pendidikan. Di dalam paradigma pendidikan semacam ini, peserta didik dilihat sebagai robot-robot patuh yang siap diperintah untuk mengejarkan sesuatu. Soal-soal keadilan sosial, nilai, etika dan hubungan kekuasaan di dalam masyarakat dijauhkan dari model pengajaran dan kurikulum pendidikan.

Giroux, pada dasarnya, hendak menantang semua bentuk pendidikan yang melihat pedagogi semata sebagai cara dan alat 
didik, guna memberikan keterampilan tertentu. Dalam konteks ini, pedagogi dilihat sebagai sesuatu yang bersifat bebas kepentingan, objektif dan universal. Artinya, ia bisa digunakan kapanpun, untuk siapapun dan dimanapun. Sebaliknya, pedagogi kritis adalah hasil dari keterlibatan sosial tertentu yang tertanam pada sebuah konteks masyarakat tertentu. Pengetahuan pun tidak dilihat sebagai sesuatu yang netral, melainkan dalam hubungan dengan kekuasaan serta struktur sosial yang sudah ada di masyarakat. Di titik ini, peserta didik dilihat sebagai manusia yang bebas dan mampu terlibat di dalam perubahan maupun pembentukan struktur sosial yang baru. Pendidikan, bagi Giroux, bukan hanya membantu peserta didik untuk menemukan kerja, tetapi juga terlibat di dalam proses pembentukan masyarakat demokratis secara menyeluruh. Di dalam masyarakat semacam ini, nilai-nilai keadilan dan kebebasan menjadi nyata di dalam keseharian. Maka, pedagogi tidak bisa dilepaskan dari politik, terutama dalam proses pembentukan manusia-manusia yang kritis dan mau terlibat di dalam proses pembangunan masyarakat secara keseluruhan (Wattimena, 2015).
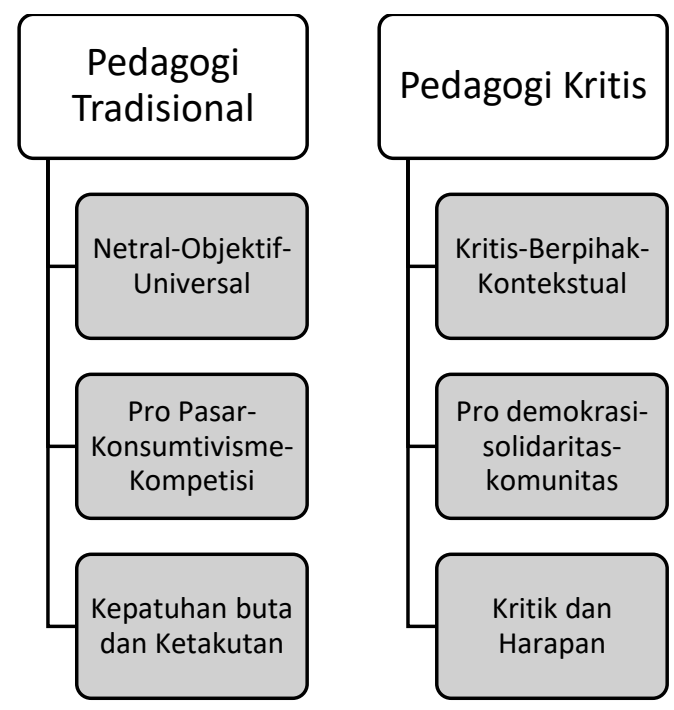

Bagan 2. Pedagogi Tradisional dan Pedagogi Kritis

Di berbagai belahan dunia, kini pendidikan dilihat sebagai barang mewah. Pendidikan bermutu menjadi amat mahal, sehingga 
hanya segelintir orang kaya yang bisa menikmatinya. Pendidikan untuk umum kerap kali jatuh pada birokasi dan formalisme agama yang membunuh kebebasan dan kreativitas. Pedagogi kritis dapat ditempatkan sebagai sebuah tanggapan kritis atas keadaan ini. Pedagogi kritis hendak membuka semua bentu penindasan budaya dan ekonomi yang membuat sekolah menjadi tempat bagi si kaya semata. Di dalam sekolah semacam ini, nilai-nilai konsumtivisme dan kompetisi menjadi nilai-nilai utama, sementara nilai solidaritas dan pentingnya komunitas terpinggirkan. Pedagogi kritis, menurut Giroux, melihat sekolah sebagai tepat perjuangan dan pemicu perubahan sosial. Ia bergerak di antara dua titik, yakni kritik (critique) terhadap keadaan masyarakat, sekaligus harapan (hope) untuk perubahan ke arah yang lebih baik.

Kritik adalah bagian penting dari pedagogi kritis. Dalam arti ini, kritik adalah sebuah penyelidikan menyeluruh terhadap sebuah fenomena sosial, termasuk budaya, institusi, ideologi dan pola hubungan sosial yang ada. Secara sederhana dapat dikatatakan, menurut Giroux, pedagogi kritis hendak melakukan kritik terhadap segala bentuk penindasan yang terjadi di dalam masyarakat, baik dalam bentuk penindasan ekonomi, politik, pendidikan maupun budaya. Contoh paling nyata adalah soal kritik terhadap pendidikan. Seringkali, pendidikan dilihat sebagai tempat membentuk manusia sesuai dengan kebutuhan perusahaan. Oleh sebab itu, budaya yang dikembangkan adalah budaya kepatuhan dan ketakutan. Pedagogi kritis hendak mempertanyakan hal ini, sekaligus melihat kemungkinan terjadinya perubahan mendasar ke arah kebebasan, keadilan, kesetaraan dan harapan. Dari kaca mata ini, sekolah bukanlah tempat persiapan karyawan-karyawan perusahaan, melainkan sebagai ruang publik demokratis, dimana nilai-nilai keadilan, kebebasan, kesetaraan dan harapan dibentuk dan dilestarikan.

Pedagogi kritis juga memiliki sisi lain, yakni sisi harapan dan kemungkinan. Dasar dari harapan dan kemungkinan ini adalah demokrasi itu sendiri yang berpijak pada kesetaraan dan kebebasan. Dua hal ini pula, yakni kebebasan dan kesetaraan, yang seringkali dikorbankan di dalam penerapan pedagogi tradisional. Pedagogi 
pendidikan mendorong anak berpikir kritis dengan kebebasan dan tanggung jawab. Pedagogi tidak boleh menjadi anak sekedar penerima pasif dari materi ajar yang berpijak pada kepatuhan buta. Dengan ketrampilan berpikir kritis, yang berpijak pada kritik dan harapan, sekolah akan menjadi tempat untuk melatih kepekaan terhadap penderitaan dan bersikap solider terhadap orang lain. Pedagogi pun berubah menjadi pendorong peserta didik untuk terlibat di dalam perubahan sosial ke arah kebebasan, demokrasi dan kesetaraan.

Dari sudut pandang pedagogi kritis, sekolah bukan hanya tempat untuk menyampaikan pengetahuan dan mengajarkan nilainilai kehidupan. Lebih dari itu, sekolah adalah tempat untuk mempertanyakan asal pengetahuan, terutama hubungan-hubungan kekuasaan di masyarakat yang menciptakan pengetahuan dan nilainilai yang ada. Dengan pola ini, pedagogi kritis menjalankan misi pendidikan yang sebelumnya telah dikembangkan oleh Paolo Freire, yakni pendidikan sebagai pembebasan dan penyadaran. Pembebasan, dalam arti ini, dipahami sebagai pembebasan dari kemiskinan dan kebodohan. Sementara, penyadaran, dalam arti ini, dipahami sebagai penyadaran orang akan posisinya di dalam masyarakat, termasuk hubungan-hubungan sosial yang membentuk dan melingkupinya (Schugurensky, 2011).

Pedagogi kritis memiliki kaitan erat dengan politik. Dengan membenturkan pendidikan dan politik, peserta didik diajarkan untuk melihat keadaan secara kritis. Dari pemahaman kritis ini, mereka lalu bisa terlibat secara bertanggungjawab di dalam melakukan perubahan sosial yang dibutuhkan. Untuk itu diperlukan kemampuan mengaitkan antara tantangan pribadi dengan tantangan sosial secara luas, karena keduanya memang tak terpisahkan. Misalnya, pergulatan seorang pribadi untuk mencari pekerjaan terkait dengan isu pertumbuhan ekonomi serta tata kelola ekonomi yang dilakukan pemerintah secara umum. Kesulitan seorang mahasiswa membayar uang kuliah terkait dengan tata kelola institusi pendidikan secara umum, termasuk paradigma pendidikan nasional yang digunakan negara terkait. Dalam arti ini, yang privat tidak pernah bisa dilepaskan dari yang publik. 
Pedagogi kritis juga menyentuh persoalan identitas, terutama identitas peserta didik sebagai manusia yang mampu terlibat di dalam pembentukan struktur sosial yang melingkupi kehidupannya (Giroux, 2011). Kemampuan ini disebut juga sebagai kemampuan agensi. Pedagogi kritis hendak mengembangkan kemampuan agensi ini yang sebenarnya sudah selalu dimiliki oleh peserta didik, namun tertutup oleh paradigma pedagogi tradisional yang membunuh kreativitas dan kebebasan (Nida-Rümelin, 2013). Agensi, sebagai konsep identitas yang aktif mencipta, adalah inti utama dari semua gerakan sosial yang menuntut perubahan sosial ke arah terciptanya masyarakat yang lebih bebas, adil, makmur dan setara. Pandangan tentang peserta didik sebagai mahluk yang aktif mencipta (agensi) ini juga memiliki dampak epistemologis.

Di dalam pedagogi tradisional, pengetahuan adalah sebuah kepastian yang harus dihafal dan dikuasai. Sementara itu, di dalam pedagogi kritis, pengetahuan adalah sesuatu yang mesti diolah, sebelum dipercaya begitu saja. Pengolahan terjadi melalui pertanyaan dan pembuktian terlebih dahulu. Dengan pola ini, pengetahuan yang ada bisa mendorong peserta didik menjadi warga negara yang terlibat secara aktif, yang siap mempertanyakan segala bentuk informasi yang tersebar luas di masyarakat. Namun, bukan hanya mempertanyakan, para peserta didik tersebut lalu mampu membuat penilaian moral yang seimbang terkait dengan keadaan yang ada, dan bertindak sesuai kebutuhan. Di titik ini, pedagogi kritis terkait langsung dengan unsur terpenting beragam gerakan sosial di dunia yang ingin mewujudkan perubahan sosial, yakni tanggung jawab moral (Wattimena, 2015).

Pada akhirnya, tujuan tertinggi dari pedagogik kritis adalah membantu peserta didik untuk menjalani hidup yang bermakna. Di dalam hidup ini, mereka mampu mempertanyakan segala bentuk hubungan kekuasaan yang ada, dan membuatnya berfungsi untuk menciptakan kebaikan bersama (common good). Dengan pedagogi kritis, peserta didik juga dididik untuk memiliki kemampuan, pengetahuan serta keberanian untuk mempertanyakan segala kebiasaan lama yang sudah dilakukan. Itu semua dilakukan untuk membentuk dunia yang lebih adil, bebas dan setara. Oleh karena itu, 
pedagogi kritis adalah pendekatan yang berakar pada konteks sosial dan sejarah sebuah komunitas tertentu. Ia tidak mendaku netral dan universal, seperti pada pedagogi tradisional. Pedagogi kritis terkait amat erat dengan cita-cita demokrasi yang sejati, dimana setiap warga negara mampu dan mau terlibat di dalam setiap pembuatan kebijakan yang terkait dengan hidup bersama (Habermas, 1989).

Giroux juga mengamati, bahwa dunia pendidikan global sekarang ini telah mengalami proses komodifikasi. Artinya, pendidikan menjadi barang dagangan dengan tujuan utama mencari dan mengembangkan keuntungan ekonomis. Segala tujuan lain disingkirkan, demi tujuan tersebut. Pedagogi kritis tentu ingin menanggapi kecenderungan yang merugikan pendidikan ini. Kecenderungan komodifikasi pun tidak hanya terjadi di pendidikan, tetapi di seluruh bidang kehidupan. Kebudayaan, sebagai ekspresi kehidupan dan peradaban tinggi, kini dilihat semata sebagai barang yang bisa diperjualbelikan, guna mencapai keuntungan ekonomis. Inilah yang kiranya disebut Herbert Marcuse sebagai manusia satu dimensi, ketika dimensi ekonomi menjadi keseluruhan ukuran dari kehidupan itu sendiri (Marcuse, 1994). Di dalam ranah ekonomi yang berpijak pada neoliberalisme, ini juga disebut kecenderungan homo oeconomicus, yakni ketika seluruh tata kelola ekonomi didasarkan pada motif untuk mencari keuntungan dari manusia, yang sebenarnya hanya merupakan satu sisi dari dirinya (Priyono, 2007).

Untuk menanggapi kecenderungan komodifikasi budaya, Giroux kemudian mengembangkan kosep pedagogi publik (Public Pedagogy). Dalam arti ini, pedagogi tidak lagi melulu ditempatkan di dalam ranah pendidikan, tetapi juga ranah budaya sebagai keseluruhan. Budaya populer, yang seringkali tampil di dalam media umum, pun dilihat tidak hanya sebagai alat hiburan, melainkan juga alat pendidikan. Beragam informasi dan pengetahuan disebarkan ke masyarakat, guna membantu hidup mereka. Beragam kecenderungan yang merusak, seperti komodifikasi pendidikan dan budaya, ditanggapi secara kritis, dan dicari jalan keluarnya. Gejala komodifikasi ini sebenarnya adalah satu bagian dari gejala yang lebih luas, yakni menyebarnya neoliberalisme. Dalam arti ini, neoliberalisme adalah versi ekstrem dari fundamentalisme pasar, 
dimana segala bentuk peraturan yang menata kehidupan ekonomi dihilangkan, sehingga hukum rimba ekonomi bisnis bisa berjalan tanpa halangan. Ilusi yang diharapkan adalah, bahwa kemakmuran bisa tercipta dari proses ini (Wibowo, 2001).

Neoliberalisme juga akan secara langsung membunuh segala bentuk dialog dan pemikiran kritis tentang perubahan sosial. Dialog dan pemikiran kritis hanya akan digunakan untuk menemukan caracara baru menciptakan dan memasarkan barang atau jasa tertentu. Yang lebih parah, orang-orang yang menerapkan pedagogi kritis dan pedagogi publik di dalam keseharian mereka justru disingkirkan dari berbagai organisasi dan institusi, terutama yang terkait dengan pendidikan. Pendidikan, dan tata kelola kehidupan bersama, pun berubah menjadi semata-mata upaya untuk menciptakan kepatuhan khas seorang pekerja yang rajin, tanpa sikap kritis dan keterlibatan untuk perubahan sosial. Sekolah dan pendidikan pun tidak lagi membicarakan soal hubungan-hubungan kekuasaan yang ada di masyarakat, melainkan justru mengabdi pada penguasa yang ada, tanpa tanya.

Pada titik ini, sekolah dan sistem pendidikan secara umum menjadi semacam penjara bagi guru dan murid. Mereka tidak dapat terlibat di dalam menentukan kebijakan pendidikan yang paling tepat untuk perkembangan peserta didik. Pekerjaan mereka diisi dengan administrasi dan birokrasi yang tidak ada hubungan langsung dengan dunia pendidikan sebagai keseluruhan. Fokus mereka pun hanya membentuk manusia-manusia patuh yang pandai menyelesaikan tes dan tugas, seperti robot-robot yang tak berpikir. Pendidikan pun disempitkan semata untuk memenuhi kepentingan bisnis dan industri, serta mengabaikan tujuan-tujuan pendidikan lainnya yang lebih dalam dan lebih luas. Tugas menghafal dihargai lebih tinggi dari pada analisis dengan menggunakan pemikiran kritis. Kepatuhan dihargai lebih tinggi dari pada kreativitas. Kompetisi untuk menjatuhkan lawan dihargai lebih tinggi, daripada kerja sama yag berpijak pada solidaritas (Giroux, 2011).

Walaupun merusak dan merugikan banyak pihak, pola pendidikan semacam ini terus diterapkan, tanpa adanya sikap kritis. Peserta didik dilihat sebagai konsumen atau klien yang memiliki 
banyak uang. Sementara, anak-anak miskin kerap kali kesulitan mendapatkan pendidikan bermutu, bahkan tidak mendapat pendidikan sama sekali. Akibatnya, mereka sulit untuk mendapatkan pekerjaan yang layak, terjebak di dalam rantai kriminalitas, sehingga harus menjadi penghuni tetap penjara. Inilah rantai sebab akibat yang mendorong meningkatnya kemiskinan dan kriminalitas di berbagai tempat. Rantai sebab akibat yang sama bisa dirunut untuk melihat akar penyebab dari menyebarnya radikalisme, fanatisme dan fundamentalisme agama di berbagai tempat, terutama sebagai reaksi keras terhadap neoliberalisme di bidang pendidikan.

Inilah yang disebut Giroux sebagai pedagogi neoliberal, dimana pendidikan sepenuhnya mengabdi pada kepentingan penumpukan keuntungan ekonomis. Untuk itu, segala bentuk pemikiran kritis pun dikekang, dan pemikiran tradisional konservatif dikembangkan menjadi bagian dari sistem pendidikan secara keseluruhan. Salah satu bentuk pemikiran tradisional konservatif berkembang dari ajaran agama yang ditafsirkan secara tradisional. Inilah yang terjadi di Indonesia, yakni formalisme agama yang menggerogoti sistem pendidikan nasional, serta membunuh segala bentuk pemikiran kritis (Wattimena, 2018). Di dalam suasana pendidikan semacam ini, segala bentuk pertanyaan dan pencarian kritis dianggap sebagai sesuatu yang tak bermoral, bahkan menghina agama serta tradisi.

Di dalam pedagogi neoliberal, akal budi digunakan hanya untuk satu tujuan, yakni mengumpulkan keuntungan ekonomis, berapapun harga yang harus dibayar. Akal budi dijadikan alat justru untuk tujuan-tujuan yang tidak masuk akal. Ini kiranya sejalan dengan analisis yang dibuat oleh Sekolah Frankfurt tentang akal budi instrumental (instrumentelle Vernunft) (Adorno, 1969). Tidak hanya pendidikan, neoliberalisme juga menghantam pola hidup masyarakat secara umum. Warga negara dilihat semata sebagai calon konsumen yang siap membeli barang, tanpa pertimbangan kritis. Pendidikan politik masyarakat pun tidak berjalan, karena ruang publik dipenuhi dengan iklan yang menggoda hasrat membeli yang nyaris tak terbatas. Pembicaraan tentang demokrasi pun semakin sedikit, dan menjadi semakin tak beradab. Demokrasi hanya dilihat sebagai cara 
untuk merebut kekuasaan dengan menggiring suara rakyat melalui penipuan dan penyebaran ketakutan.

Ciri khas dari pedagogi kritis, menurut Giroux, adalah kepekaannya terhadap segala bentuk permasalahan sosial yang ada di masyarakat. Khusus di abad 21, pedagogi kritis hendak mengajukan sikap kritis terhadap dua hal, yakni kecenderungan totalitarisme di dalam masyarakat dengan menggunakan identitas-identitas primordial, dan kecenderungan menyebarnya pola pikir neoliberalisme, seperti sudah dijelaskan sebelumnya. Dalam hal ini, secara khusus, pedagogi kritis hendak memperjuangkan kepentingan kaum muda yang masih memiliki banyak kemungkinan untuk menjadi pendorong perubahan sosial. Pedagogi kritis menyediakan konsep-konsep yang diperlukan untuk berpikir kritis di dalam menyingkapi keadaan masyarakat yang ada, termasuk hubunganhubungan sosial yang berada di belakangnya. Dengan inilah pedagogi kritis dapat memperkaya paradigma sekaligus sistem pendidikan yang sudah ada.

Pedagogi neoliberalisme telah membunuh pendidikan, begitu kata Giroux. Ia telah membuat peserta didik menjadi semacam zombie, yakni manusia yang telah kehilangan kemanusiaannya, walaupun belum mati sepenuhnya. Seluruh sistem pendidikan, termasuk politik dan ekonomi di belakangnya, telah mendorong orang untuk menjadi zombie. Walaupun begitu, lanjut Giroux, harapan masih ada. Pedagogi kritis bisa menjadi sudut pandang baru untuk menantang tersebarnya pedagogi neoliberal (Giroux, 2011). Ia bisa menjadi tolok ukur akan apa arti dari pendidikan sesungguhnya. Ia tidak mengikuti secara buta perhitungan matematis untuk mengukur kompetensi peserta didik. Ia menggunakan, sekaligus melampaui itu semua. Pedagogi kritis hendak membangun kemanusiaan dalam bentuk pemikiran kritis dan kepekaan moral di dalam menilai keadaan, serta bertindak. Semua ini adalah sumber dari solidaritas dan gerakan sosial untuk menciptakan perubahan sosial yang mengarah pada kebaikan bersama.

Indonesia juga sudah cukup lama menyaksikan tersebarnya pola pikir neoliberalisme di berbagai ranah kehidupan. Politik diperjualbelikan layaknya dagangan di pasar. Hampir setiap hari, 
rakyat menyaksikan berita korupsi yang tersebar di seluruh Indonesia. Diskusi tentang demokrasi pun tertutup oleh fanatisme dan radikalisme agama. Pelajar dan mahasiswa menjadi apolitis, karena dididik untuk mengabdi kepentingan pasar dan bisnis semata. Semua bentuk pemikiran dan pertanyaan kritis justru ditakuti, bahkan hendak dihancurkan atas nama kepatuhan buta terhadap apa kata penguasa, baik penguasa politik, agama maupun penguasa bisnis. Dalam hidup sehari-hari, hukum rimba pun menjadi hukum utama. Siapa yang kaya dan berkuasa, dia yang akan selamat. Mereka yang miskin dan tak punya kuasa akan terus hidup dalam kemiskinan, dan menjadi korban.

Sebagai sebuah ideologi, neoliberalisme melihat kompetisi sebagai jalan bagi tata kelola hidup bersama. Orang memikirkan keselamatan dirinya sendiri, dan jika perlu mengorbankan orang lain, demi keselamatannya. Kreativitas dan pikiran kritis hanya diterapkan untuk mengembangkan produk baru yang lalu dijual di dalam iklim ekonomi pasar yang sangat kompetitif dan individualis. Nilai-nilai luhur kehidupan, seperti solidaritas dan kemanusiaan, disingkirkan, demi penumpukan keuntungan yang tanpa batas. Dalam arti ini, pendidikan berubah menjadi sekedar budak dari ekonomi dan bisnis. Pendidikan pun dinilai dengan menggunakan tes-tes tak masuk akal, guna disesuaikan dengan tujuan pertumbuhan ekonomi dan peningkatan pendapatan individual. Sayangnya, pola pendidikan semacam inilah yang diikuti di Indonesia.

Paradigma pendidikan neoliberal, sebagaimana dijabarkan oleh Giroux, amat menekankan kemampuan-kemampuan untuk memenangkan kompetisi di dalam dunia bisnis. Seluruh proses pendidikan pun ditentukan oleh tiga hal, yakni sistematisasi pembelajaran, hafalan mutlak dan tes-tes yang wajib terus dilakukan. Peserta didik dilihat sebagai mesin-mesin yang harus patuh pada perintah pengajarnya. Pola semacam ini jelas membunuh budaya berpikir kritis, sistematis dan keterlibatan di dalam perubahan sosial yang justru amat diperlukan di dalam perkembangan masyarakat demokratis. Peserta didik yang tidak dapat menjalankan proses ini dianggap sebagai bodoh, sehingga perlu menjalankan beberapa prosedur terapi khusus untuk menjinakannya. 
Di dalam masyarakat neoliberal semacam ini, nilai seorang manusia diukur dari daya belinya. Jika ia miskin dan tak memiliki daya beli yang kuat, ia dianggap sebagai warga negara kelas dua. Jika seseorang berhasil menjadi kaya secara ekonomis, ia lalu dilihat sebagai tokoh masyarakat yang berpengaruh. Kekayaan pun dilihat sebagai melulu hasil dari usaha pribadi. Sebab-sebab struktural yang melahirkan kekayaan dan kemiskinan diabaikan. Ini jelas bertentangan dengan kenyataan yang ada. Secara luas, nilai-nilai hidup bersama, seperti solidaritas dan demokrasi, pun terkikis. Nilainilai pribadi, seperti kompetisi, kemenangan dan kekayaan ekonomi diri, menjadi hal-hal yang dianggap berharga di masyarakat. Hal yang sama kiranya terjadi di dunia pendidikan. Pedagogi neoliberal melepaskan nilai-nilai hidup bersama dari isi dan cara pengajaran.

Pada akhirnya, menurut Giroux, pendidikan haruslah menyadarkan peserta didik tentang identitasnya. Dalam arti ini, identitas bukanlah sesuatu yang langsung selesai, melainkan selalu dalam proses pembentukan yang berkelanjutan. Di dalam proses ini, pemahaman yang mendalam tentang hubungan antara diri dan lingkungan sekitar menjadi amat penting. Sikap peka terhadap keadaan sekitar, dan upaya untuk terlibat aktif di dalam perubahan sosial, menjadi bagian dari proses pembentukan identitas. Pedagogi kritis juga bukanlah upaya untuk menemukan kebenaran dan membentuk pengetahuan semata. Ia bergerak lebih jauh untuk mendorong orang menjadi peka dan kritis terhadap keadaan sekitarnya, dan terlibat di dalam upaya untuk mendorong terciptanya kebaikan bersama. Dalam arti ini, pedagogi kritis merupakan sebuah tindakan moral sekaligus tindakan politik.

Pendidikan selalu lahir dari konteks sosial tertentu. Pendidikan juga bisa berfungsi dua hal, yakni memberi dasar pembentukan pengetahuan, dan mengajarkan sikap kritis terhadap konteks sosial yang menjadi latar belakang pengetahuan tersebut. Dari dua hal ini, tentu saja pendidikan tetap harus melakukan analisis tentang hubungan-hubungan kekuasaan yang ada di dalam masyarakat. Hanya dengan begini, pendidikan lalu bisa menawarkan cara pandang baru yang mampu mendorong perubahan masyarakat ke arah yang lebih baik. Di sinilah pentingnya pendidikan sebagai agen 
pembentuk masa depan. Tanpa upaya untuk mempertanyakan keberadaan struktur sosial yang ada secara kritis, pendidikan justru melestarikan keadaan sekarang, sekaligus membenarkan hubunganhubungan kekuasaan yang tidak adil.

Giroux jelas mendapatkan banyak inspirasi dari Paulo Freire, seorang pemikir pendidikan asal Brasil. Di dalam kaca mata Freire, pendidikan haruslah dibalut dengan keberanian intelektual dan politis (Moral and Intellectual Courage). Inilah jantung hati dari pedagogi kritis yang dirumuskan juga oleh Freire sebelumnya. Pendidikan adalah soal politis. Yang pribadi dan yang politis tidaklah bisa dipisahkan secara hitam putih. Sebagai bagian dari dunia pendidikan, kaum intelektual juga memiliki tanggung jawab politis (Political Responsibility). Mereka tidak bisa netral dan memilih berdiam diri di dalam bidang keilmuannya. Dengan didorong oleh kepekaan moral dan ketajaman analisis, mereka terlibat di dalam berbagai upaya untuk mewujudkan kebaikan bersama di dalam masyarakat. Ilmu pengetahuan dan gerakan sosial pun lalu terhubung untuk mendorong perubahan sosial. Ini menjadi amat penting di abad 21, ketika ilmu pengetahuan digunakan semata sebagai alat untuk menindas dan menjajah.

\section{PEDAGOGI KRITIS DAN CATATAN KRITIS UNTUK INDONESIA}

Ada lima catatan yang kiranya bisa diberikan kepada pemikiran Giroux, terutama dalam konteks Indonesia, seperti yang tertera pada Bagan 1. Satu, sama seperti analisis Giroux, Indonesia pun mengalami tersebarnya pedagogi neolliberal di dalam pendidikan. Pendidikan pun disempitkan menjadi semata pengajaran kemampuan-kemampuan untuk menang di dalam kompetisi bisnis. Nilai-nilai luhur pendidikan, seperti kemanusiaan, sikap kritis, kepekaan moral, keterlibatan sosial dan demokrasi, pun terpinggirkan. Di dalam alam pikir neoliberalisme, uang dan ekonomi menjadi satu-satunya ukuran bagi semua bidang kehidupan manusia (Wibowo, 2001). 


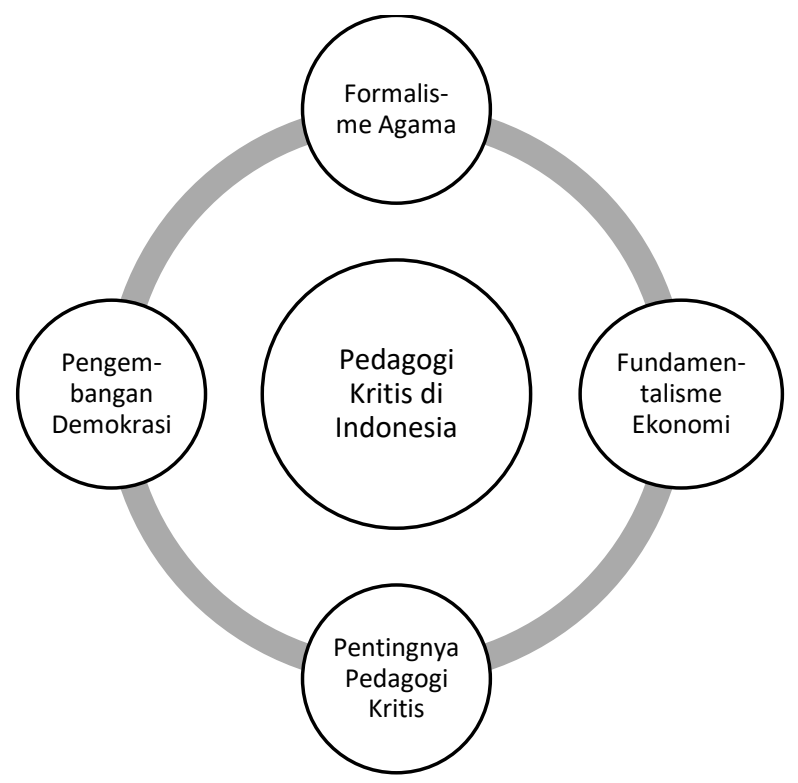

Bagan 3. Pedagogi Kritis

Dua, di Indonesia, pendidikan juga dijajah oleh formalisme agama, yakni pemahaman agama yang terjebak pada ritual dan aturan-aturan buta, tanpa pemahaman akan inti dari agama tersebut. Pendidikan formalistik religius semacam ini jelas bertentangan dengan cita-cita bangsa Indonesia untuk mencerdaskan kehidupan bangsa, sekaligus mewujudkan masyarakat yang adil dan makmur. Yang tercipta justru sebaliknya, yakni manusia-manusia yang berpikir tertutup, ketinggalan perubahan jaman, fanatik dan cenderung intoleran di dalam banyak hal. Jika tidak ditanggapi secara kritis, pola pendidikan semacam ini justru menghancurkan mental dan pola pikir para peserta didik.

Tiga, menyebarnya paham fundamentalism agama dan fundamentalisme ekonomi di dalam pendidikan membuat dunia pendidikan di Indonesia kehilangan nilai-nilai luhurnya. Peserta didik dibentuk menjadi orang yang patuh buta terhadap kekuasaan. Ia cerdas dan kreatif di dalam mematuhi perintah yang diberikan oleh para penguasa politik dan pemilik modal. Ia pun hanya peduli pada penumpukan kekayaan semata, dan menjadi tidak peduli terhadap beragam permasalahan sosial yang mengancam keutuhan hidup 
bersama. Dengan kata lain, pendidikan telah kehilangan roh sejatinya, dan menjadi semata pengajaran kepatuhan buta terhadap penguasa (Nida-Rümelin, 2013).

Empat, melihat keadaan Indonesia sekarang ini, pemikiran Giroux tentang pedagogi kritis jelas amat dibutuhkan. Pedagogi kritis adalah paradigma pendidikan sekaligus kehidupan yang menekankan sikap kritis terhadap hubungan-hubungan kekuasaan yang membentuk masyarakat. Sikap kritis ini dibarengi dengan wawasan luas serta kepekaan moral yang menuntut pada tindakan nyata yang membawa perubahan sosial ke arah yang lebih baik. Baik dalam arti ini adalah kebaikan bersama, dimana setiap orang bisa hidup secara bebas dalam kemakmuran dan keadilan bersama. Pedagogi kritis bergerak melampaui pedagogi tradisional yang bersifat netral dan menuntut kepatuhan buta terhadap penguasa politik maupun ekonomi yang sudah ada.

Lima, pedagogi kritis juga bisa berperan besar di dalam pengembangan demokrasi di Indonesia. Masyarakat demokratis membutuhkan warga yang mampu berpikir kritis dan rasional, guna menyingkapi berbagai persoalan yang muncul di dalam hidup bersama. Demokrasi mengandaikan warga negara yang cukup mampu membuat keputusan dan mengolah informasi secara kritis dan rasional. Ini lalu dibalut dengan kepekaan moral, wawasan yang luas serta keberanian untuk terlibat di dalam perubahan sosial. Tanpa ini semua, demokrasi di Indonesia tidak akan berjalan, dan akan terjebak pada berbagai bentuk korupsi, kolusi dan nepotisme, seperti yang banyak disaksikan sekarang ini.

Ada dua tanggapan kritis yang bisa diberikan kepada pemikiran Giroux. Pertama, konsep pedagogi kritis mengandaikan berkembangnya budaya tertentu, yakni budaya masyarakat rasional yang terdiri dari warga-warga yang mampu berpikir mandiri dan kritis. Ini menjadi sulit diterapkan di dalam budaya kolektif, dimana pemikiran kritis dan rasional dianggap mengancam keutuhan kelompok. Di dalam masyarakat semacam ini, harmoni lebih dihargai daripada diskusi maupun perdebatan yang membangun. Sebagai sebuah bangsa yang majemuk, beberapa kelompok masyarakat di Indonesia masih amat mendewakan keutuhan kelompok dan 
harmoni. Ini tentu tantangan tersendiri di dalam penerapan pedagogi kritis, sebagaimana dirumuskan oleh Giroux.

Dua, jika membaca langsung tulisan-tulisan Giroux, akan terasa begitu banyak pengulangan. Dasar teorinya pun terlihat rapuh. Muncul kesan adanya keberpihakan pada aktivisme yang melampaui kedalaman refleksi intelektual. Gerakan sosial dan kritik terhadap kekuasaan dianggap lebih penting dari kedalaman refleksi dan analisis atas keadaan yang ada. Ini tentunya bukan kelemahan fatal, karena Giroux, dan para penafsirnya, bisa memperkaya dasar teori mereka misalnya dengan menggunakan analisis para pemikir Sekolah Frankfurt. Konsep-konsep dasar Sekolah Frankfurt, seperti dialektika pencerahan, manusia satu dimensi, rasionalitas instrumental, komunikasi yang bebas dan politik pengakuan, bisa memperkaya dasar teori pedagogi Kritis yang dirumuskan oleh Giroux.

\section{SIMPULAN}

Giroux menawarkan perubahan paradigma di dalam konteks pendidikan dari pedagogi tradisional yang bersifat netral dan universal menuju pedagogi kritis yang bersifat kritis dan kontekstual. Pedagogi tradisional cenderung berpihak pada penguasa politik dan ekonomi yang ada. Sementara, pedagogi kritis memetaka hubunganhubungan kekuasaan yang ada, sehingga bisa mendorong terjadinya perubahan sosial ke arah masyarakat yang lebih terbuka, bebas dan adil. Tidak berhenti disitu, pedagogi kritis juga mengembangkan wawasan dan kepekaan moral di dalam memahami keadaan sosial. Ini semua menjadi bekal bagi keterlibatan sosial peserta didik di dalam proses perubahan sosial. Kritik utama pedagogi kritis, menurut Giroux, adalah pola pikir neoliberalis yang menempatkan ekonomi sebagai ukuran bagi segala sesuatu di dalam hidup. Dengan melihat keadaan Indonesia, serta beberapa ide dasar dari pedagogi kritis, maka dapatlah disimpulkan, bahwa pedagogi kritis amat cocok diterapkan di Indonesia.

\section{DAFTAR PUSTAKA}

Adorno, M. H. Theodor, 1969, Dialektik der Aufklärung: Philosophische Fragmente, S. Fischer, Frankfurt. 
Giroux, H., 2011, On Critical Pedagogy, The Continuum International Publishing Group, London.

---------,2018, “Henry Giroux", https://www.henryagiroux.com/ April 12.

Habermas, J., 1989, Faktizität und Geltung - Beiträge zur Diskurstheorie des Rechts und des demokratischen Rechtsstaats, Suhrkamp, Frankfurt.

Marcuse, H., 1994, Der eindimensionale Mensch: Studien zur Ideologie der fortgeschrittenen Industriegesellschaft, Deutscher Taschenbuchsverlag, München.

Nida-Rümelin, J., 2013, Philosophie einer humanen Bildung. Körber Stiftung.

Priyono, B. Herry, (2007), Sesudah Filsafat, Kanisius, Yogyakarta

Schugurensky, D, (2011), Paulo Freire, Bloombury, London.

Wattimena, Reza A.A., 2015, Filsafat sebagai Revolusi Hidup, Kanisius, Yogyakarta.

--------, 2016, Demokrasi: Dasar Filosofis dan Tantangannya, Kanisius, Yogyakarta.

--------, 2018, "Rumah Filsafat", www.rumahfilsafat.com: https://rumahfilsafat.com/2018/03/10/harian-kompas-10-maret2018-tekno-demokrasil

Wibowo, I., 2001, Negara Centeng, Kanisius, Yogyakarta. 